\title{
New Investigations of Interglacial Fresh-Water Deposits in Jutland. A Preliminary Report
}

\author{
By Svend Th. Andersen, Charlottenlund, Dänemark
}

With 2 figures in the text

\begin{abstract}
Z us a m men fas sung. Die Neu-Untersuchung vom „Brörup-Hotel-Moor“ und anderer interglazialer Fundstätten aus Jütland haben gezeigt, daß der eigentlichen letzten Interglazialzeit eine kalte Solifluktionsperiode folgte. Ein langes, temperiertes Interstadial mit Birken- und zuletzt auch Fichten- und Föhrenwäldern ging der Hauptphase der letzten Vereisung voraus. Das Interstadial wird dem Göt tweiger Interstadial und die vorhergehende kalte Periode dem Altw ü rm gleichgesetzt. Während der Solifluktionsperiode fanden Umlagerungen von interglazialem Material statt.
\end{abstract}

S ummary. A re-investigation of „Brörup Hotel Bog“ and other interglacial sites in Jutland has shown that the last interglacial proper was followed by a cold period with strong solifluction. A long temperate interstadial with birch and successively spruce and pine forests preceded the main part of the last glaciation. The interstadial period is referred to the $G \ddot{o t} t-$ we ig e r Interstadia l and the preceding cold period to the Old W u r m (A $1 \mathrm{tw}$ ü $\mathrm{m}$ ). During the solifluction period rebedding of intergiacial material took place.

Introduction. In the great survey of interglacial freshwater deposits from Jutland and Northwest Germany published by Jessen and MiLthers nearly 30 years ago (Jessen \& Milthers 1928) the „Brörup Hotel Bog“ deposit shows the most complete development of the so-called "upper warmth horizon" referred by these authors to the latter part of the last interglacial period. For a reconsideration of the interpretation of this "upper warmth horizon" with the help of modern pollen-analytical technique the „Brörup Hotel Bog“ therefore seemed the most suitable, and in 1954 a new boring was carried out and material secured for detailed pollen-analysis. New material has also been collected from the sites at Herning and Rodebaek I. The borings were carried out by the Geological Survey of Denmark and the work has further been supported by the Danish State Research Foundation. The present report gives a preliminary survey of the results especially from the former site mentioned; the full details will be published at a later occasion.

Stratigraphy. The „Brörup Hotel Bog“ interglacial deposit is situated in Jutland outside the limit of the last glaciation. Beneath a solifluction deposit of stony sand, a peat and mud deposit is found separated from the interglacial deposit proper by minerogene layers (see fig. 1. A.). The interglacial deposit consists of forest peat and beneath it lake mud extending to $9,64 \mathrm{~m}$ below the surface. The pollen diagram published by Jessen \& Milthers (1928) from the basal forest peat and mud shows a sequence characteristic of the last interglacial period as well known from other sites in $\mathrm{NW}$-Europe. The present pollen-analytical study comprises the top part of the interglacial forest peat and the younger sequence.

Rebedded pollen. Especially the studies of Thomson (1951) and West (1956) have demonstrated with great clearness that the deposits covering a waning interglacial may be seriously contaminated with rebedded older material. Through disturbances by periglacial erosion exposed interglacial deposits are likely to be destroyed and the lake basins filled with minerogene sediments contaminated with rebedded plant bearing material. For such reasons it has been suggested (cp. also Woldsted 1949) that the „upper warmth horizon“ demonstrated by Jessen \& Milthers at „Brörup Hotel Bog“, Herning and other sites should consist mainly of such rebedded material. 


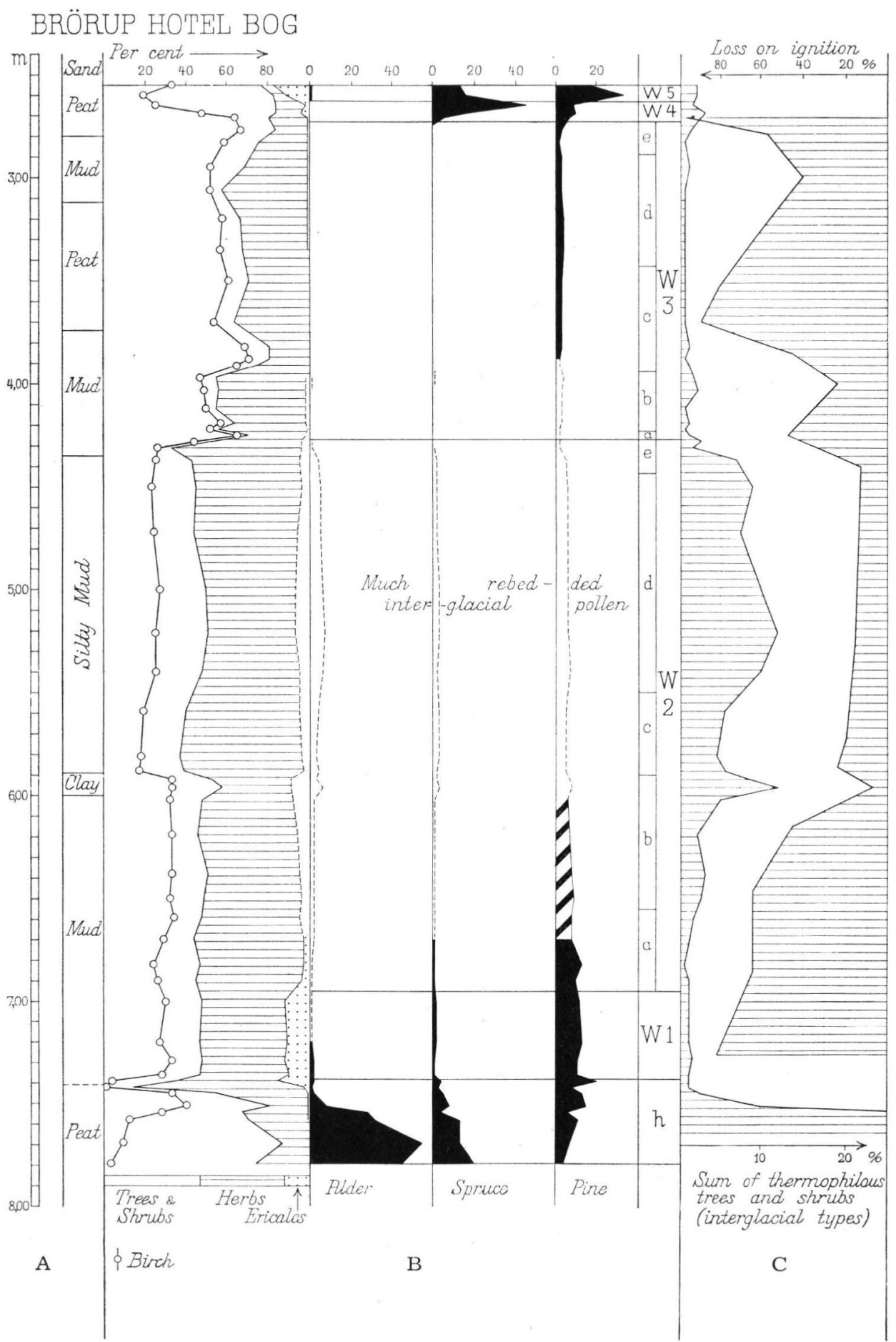

Fig. 1 (Erläuterung siehe nächste Seite unten). 
In the new pollen diagram from „Brörup Hotel Bog“ a summation curve for all definitely interglacial pollen types is compared with a curve for the loss on ignition of the samples as a measure of the intensity of minerogene influx (fig. $1 \mathrm{C}$ ). Their correlation in the predominantly minerogene layers is too obvious to need further discussion here, and there can be little doubt that in the minerogene layers above $6,90 \mathrm{~m}$ all interglacial pollen types are in fact washed into the deposits through erosional processes. The influence of rebedded material is moderate, however, and it has been possible to separate the other members of the pollen flora into primary and secondary elements by their rate of correlation with the curve for definitely secondary pollen types. The curves of pine, spruce and Ericales thus show a high correlation with the interglacial types in the levels $3,90-6,60 \mathrm{~m}$, and there is little doubt as to their secondary origin here, while other curves such as grasses, sedges and Artemisia show negative correlation. Of special interest is the very high loss on ignition in pollen zone W 4 (at 2,70 m) - 97\% - indicating no influx whatsoever. The much pine and spruce pollen from this level certainly is of primary origin.

Vegetationalsuccession. The main features of the vegetational succession illustrated by the pollen diagram in fig. 1 are summarized below. The pollen zones W 1-5 follow the principles proposed by SELLE (1953) but are not identical to his zones, as the details of the development are different. The zones are defined in terms of vegetational change, not by climate or glaciology. Pollen zone $\mathrm{h}$ is in accordance with the system in Jessen \& Milthers (1928).

Polle $\mathrm{nz}$ one h. In this zone the pollen in the Brörup Bog is essentially of local origin and records an alder-spruce swamp forest being replaced by birch and pine with increasing abundance of local herbs. During the zone the thermophilous forest trees and shrubs disappear.

Pollen zone W1. The forest has disappeared and the vegetation is rich in dwarf birch (cp. fig. 2), herbs and heath plants, but scattered tree birches and pines still persist.

Pollenzone W2. This zone represents the coldest part of the sequence. During the thermal minimum the vegetation is dominated by herb vegetation rich in grasses and sedges. Due to solifluction the leached soil formed in the interglacial period is destroyed and base rich soil is brought to the surface as demonstrated by the appearance now of a rich flora of calciphilous and ruderal plants. The sub-zones W 2 a-e are based on details of the herb pollen curves and reflect minor climatic oscillations. During the coldest parts, the subzones $\mathrm{b}$ and $\mathrm{d}$, the solifluction was very intensive and the country almost bare of vegetation. A lake is re-created in the local basin.

Pollen z on e W 3. Tree birch again becomes dominant (cp. fig. 2.) and from the beginning of the zone thermophilous herbs indicate a temperate climate. Minor oscillations in the herb pollen frequency are recorded in the sub-zones W 3 a-e. In the cooler sub-zones $\mathrm{b}$ and $\mathrm{d}$ some soil erosion continues. The minor climatic oscillations are reflected in changes of the local water table.

Fig. 1. Simplified pollen diagram from the profile at „Brörup Hotel Bog“. A. Stratigraphy. B. Pollen curves. The composite diagram illustrates the relationships between trees and shrubs, herbs, and heath vegetation (Ericales), and individual curves for birch, alder, spruce and pine are shown. C. Summation curve for thermophilous trees and shrubs (mixed oak forest trees; alder, hazel, holly etc.) with certainty of secondary origin compared with a curve for the loss on ignition. The minima of loss on ignition indicate strong minerogene influx during periods of erosion. In pollen zone W 2 the influx of minerogene matter and of rebedded pollen is relatively high. In the zones W 3-5 the intensity of erosion is lower; here the frequency of rebedded pollen is suppressed by the heavy pollen production of the contemporaneous birch forests. 


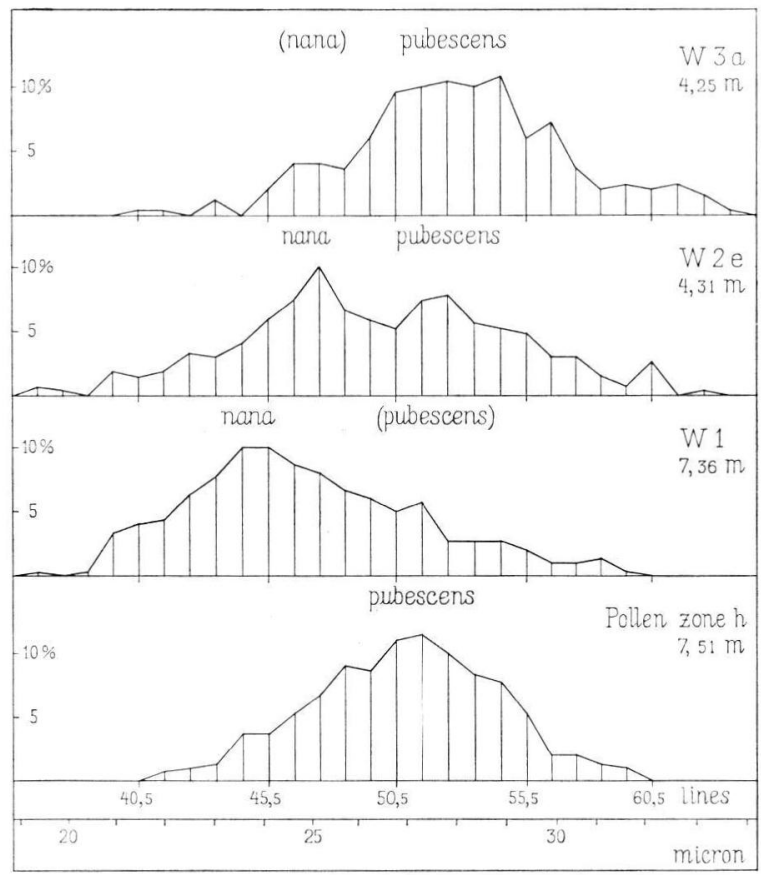

Fig. 2. Four examples of size-frequency curves for the fossil birch pollen. They illustrate the changes in relative abundance of dwarf birch (Betula nana) and tree birch (B. pubescens), both species identified from macroscopic remains by Jessen (Jessen \& Milthers 1928). Dwarf birch has the smallest pollen, and the modes of the two species are separated by the use of a very small size class ( 0.56 micron) during the measurements. Each curve is based on a total of ca. 300 pollen grains.

Pollen zone W4. Spruce and pine re-immigrate and spruce forests once again become the dominant feature of the landscape. The slight rise in the frequency of thermophilous trees and shrubs is likely here to represent far distance transportation.

Polle n z o n e W 5. Spruce is replaced successively by pine and birch. Progressive soil leaching is indicated by the rise of heath plants. The climate is cooling off. The covering solifluction earth most probably was formed in the period of maximum cold of the last glaciation.

Discussion and correlations. The strongly delayed re-immigration of pine and spruce in the favourable zones W 3-5 cannot be due to climatic causes and must be ascribed to incomplete immigration. Apparently the preceding zone W 2 was so cold that even these northern forest trees were displaced very far to the south. Incomplete re-immigration probably also caused the oak forest trees to be totally absent during the warmth oscillation, which becomes highly resemblant of the temperate Alleröd Interstadial from the late Würm glaciation (cp. IvERSEN 1954) - although its duration must have been longer. Following the paleobotanical definition given by Gross (1956) it seems best now to consider the upper mud horizon from Brörup as interstadial. During the cold period preceding the interstadial zones periglacial conditions must have prevailed in Northern Europe. We have no information, whether the continental glacier was present in Denmark at that time, but it seems justified to consider zone W 2 as representing the first cold phase of the last glaciation.

Already during pollen zone $\mathrm{h}$ the warm interglacial climate begins deteriorating. At the same time progressive soil leaching leads to the dominance of acidophilous 
plants. The end stage of the interglacial cycle, the subarctic heath vegetation of zone W 1, disappears when the solifluction processes start creating again the raw, mineral soil conditioning the presense of a glacial flora. In the Brörup diagram this transition is clearly indicated by the abrupt decline of the Ericales at the zone transition W $1-2$, where also the first calciphilous plants appear. As the initiation of intensive solifluction due to a deteriorating climate will depend on local conditions such as topography and clay content of the soil, this border however important paleobotanically is unsuitable for a delimitation between the interglacial and the glacial pollen zones, and it seems preferable to consider the first forestless period as the oldest glacially conditioned pollen zone, zone W 1.

The new pollen diagrams from the famous Herning site have confirmed the suggestions by Woldstedt and others(Woldstedt 1949, 1955, Thomson 1951, West 1956) that the "upper warmth horizon" there with an abundance of remains of temperate plants consists mainly of rebedded interglacial material, but a gyttja horizon (JESSEN \& Milthens' layer F) has proved to be primary and to be contemporaneous with subzone W 3a from the new Brörup diagram.

The lower Würm or Weichsel stratigraphy especially of Central Europe has been discussed intensively in this periodical during the recent years (see especially Zeuner 1954, Brandtner 1954, 1956, Woldstedt 1956, Gross 1956 and others). Evidence from a variety of fields, paleontology as well as pedology and glaciology, now confirms the view that an interstadial just as warm, but considerably longer than the Alleröd separated an Old W ü rm ( A l t w ü $\mathrm{rm}$ ) cold phase from the $M$ a in W ü $\mathrm{rm}$ ( $\mathrm{Hauptw}$ ürm). It is the Göttweiger interstadial of Gross (1956) named after a soil horizon in the Younger Löss from Lower Austria originally described by BAYER as interglacial and equivalent to the Fellabrun er Boden bildungs$\mathrm{komplex}$ of Brandtner (1954). There can be little doubt that this interstadial is the same as the one now recognized in the "Brörup Hotel Bog“ profile. From Northern Germany a number of interstadial peat and mud deposits from the covering layers of Riß/Würm interglacials are known (see i. a. Gross 1956) but a detailed correlation cannot be attempted here. The interstadial deposit from Loopstedt near Slesvig described by Kolumbe (1955) seems to be the most complete, it will probably prove to be an equivalent of the deposits just described.

\section{Lit terature}

Brandtner, F.: Jungpleistozäner Löß und fossile Böden in Nieder-Österreich. - Eisz. u. Geg. 4/5, S. 49-82, 1954. - - Lößstratigraphie und paläolithische Kulturabfolge in Niederösterreich und in den angrenzenden Gebieten. - Eisz. u. Geg. 7, S. 127-175, 1956.

Gross, H.: Das Göttweiger Interstadial, ein zweiter Leithorizont der letzten Vereisung. Eisz. u. Geg. 7, S. 87-101, 1956.

Iversen, J.: The late-glacial flora of Denmark and its relation to climate and soil. - Danm. Geol. Unders. II. Ser. 80, S. 87-119, 1954.

Jessen, K. \& Milthers, V.: Stratigraphical and paleontological studies of interglacial freshwater deposits in Jutland and Northwest Germany. - Danm. Geol. Unders. II. Ser. $48,1928$.

Kolumbe, E.: Über interglaziale und interstadiale Bildungen von Loopstedt am Haddebyer Noor bei Schleswig. - Eisz. u. Geg. 6, S. 39-40, 1955.

SELLE, W.: Gesetzmäßigkeiten im pleistozänen und holozänen Klimaablauf. - Abh. naturw. Verein Bremen 33, S. 259-290, 1953.

Thomson, P. W.: Das Interglazial von Wallensen im Hils. - Eisz. u. Geg. 1, S. 96-102, 1951.

West, R. G.: The quaternary deposits at Hoxne, Suffolk. - Phil. Trans. Royal Soc. London, Ser. B, No. 665, Vol. 239, S. 265-356, 1956. 
WoldstedT, P.: Uber die stratigraphische Stellung einiger wichtiger Interglazialbildungen im Randgebiet der nordeuropäischen Vergletscherung - Z. deutsch. geol. Ges. 99, S. 96 bis 123, 1950. - - Die Gliederung des Pleistozäns in Norddeutschland und angrenzenden Gebieten. - Geol. Fören. Förhandl. Stockh. 77, S. 525-545, 1955. - - Uher die Gliederung der Würm-Eiszeit und die Stellung der Lösse in ihr. - Eisz. u. Geg. 7, S. $78-86,1956$.

Zeuner, F. E.: Riss or Würm? - Eisz. u. Geg. 4/5, 98-105, 1954.

Manuskr. eingeg. 10. 5. 15,57.

Anschrift des Verfassers: Svend Th. Andersen, Danmarks Geologiske Undersøgelse, Charlottenlund, Dänemark. 